Systematic Review

\title{
Surgical Interventions in Cases of Esophageal Hiatal Hernias among Older Japanese Adults: A Systematic Review
}

\author{
Yuta Horinishi ${ }^{1,2}$, Kai Shimizu ${ }^{3}$, Chiaki Sano ${ }^{2} \mathbb{D}$ and Ryuichi Ohta ${ }^{4, *}$ \\ 1 Matsue Seikyo General Hospital, 8-8-8 Nishituda, Matsue 690-8522, Shimane, Japan; \\ yuuta881219@yahoo.co.jp \\ 2 Department of Community Medicine Management, Faculty of Medicine, Shimane University, \\ Izumo 693-8501, Shimane, Japan; sanochi@med.shimane-u.ac.jp \\ 3 Huchu Hospital, 1-10-17, Huchu-Town, Izumi 594-0076, Osaka, Japan; lkaaishimi7738@gmail.com \\ 4 Community Care, Unnan City Hospital, 96-1 Iida, Daito-cho, Unnan 699-1221, Shimane, Japan \\ * Correspondence: ryuichiohta0120@gmail.com
}

Citation: Horinishi, Y.; Shimizu, K.; Sano, C.; Ohta, R. Surgical Interventions in Cases of Esophageal Hiatal Hernias among Older Japanese Adults: A Systematic Review. Medicina 2022, 58, 279. https://doi.org/10.3390/ medicina58020279

Academic Editor: Theodore Chan

Received: 7 January 2022

Accepted: 11 February 2022

Published: 13 February 2022

Publisher's Note: MDPI stays neutral with regard to jurisdictional claims in published maps and institutional affiliations.

Copyright: (C) 2022 by the authors. Licensee MDPI, Basel, Switzerland. This article is an open access article distributed under the terms and conditions of the Creative Commons Attribution (CC BY) license (https:// creativecommons.org/licenses/by/ $4.0 /)$.

\begin{abstract}
Background and Objectives: Given Japan's superaging population, an increasing number of older adults in the country need surgical treatment for esophageal hiatal hernias. Accordingly, this systematic review examines surgical interventions for symptomatic esophageal hiatal hernias in older Japanese patients and explores treatment outcomes. Materials and Methods: Articles on single operations for hiatal hernias published after 1991 were found on Google Scholar and Ichushi using specific keywords. Subsequently, articles fulfilling the predetermined inclusion criteria were considered in the study. Results: The mean patient age was 81.4 years, and the male-to-female ratio was 1:11.5. The main reasons for surgery were vomiting, dyspnea, and chest tightness. In terms of hernia classification, type IV was the most common (48\%). Surgical modalities were laparoscopy in 15 cases, and laparotomy in 10 cases. Mean postoperative course was 26.47 days until hospital discharge, and there were no cases of perioperative death. Conclusions: Findings showed that multiple factors were involved in older adults' prognoses, and age was not the only biological factor. Therefore, aggressive surgical intervention should be considered for symptomatic older patients, even in the absence of surgery indicators.
\end{abstract}

Keywords: esophageal hiatal hernia; surgery; Japan; older adults; ageism

\section{Introduction}

A hiatal hernia is the most common type of diaphragmatic hernia and is a relatively common disease, especially among older adults. This condition refers to the intraabdominal organs overhanging into the thoracic cavity. According to a national survey conducted by the Society for Gastroesophageal Reflux Disease in Japan, hiatal hernias occur in $49.3 \%$ of individuals who undergo upper endoscopies, and are more common in men and older adults. With the increase in global population aging, the prevalence of this disease is also increasing [1] for reasons such as weakening of the diaphragmatic esophageal ligament, dilatation of the esophageal hiatus due to vertebral body fracture, gibbus deformity, obesity, and an increase in abdominal pressure [2]. There are four types of hiatal hernias: sliding (type I), pure paraesophageal (type II), mixed (type III), and complex (type IV) [3]. Type I is the most common (approximately 95\% of the cases), while the prevalence of each of the other types is under 1\% [4]. Hiatal hernias can cause several problems. The most common symptom of type I hernia is gastroesophageal reflux disease. Types III and IV, which are most common in older women, can cause dysphagia, passage disorder, anemia, strangulation, and aspiration pneumonia. Among the cases of esophageal hiatal hernia, relatively few cause respiratory and circulatory disorders [5]. Nevertheless, cases requiring emergency surgery include those where patients exhibit an incarcerated hernia, a prolapse, a gastric axis twist, a respiratory disorder due to lung compression [6], 
and arrhythmia due to cardiac compression [7]. Therefore, careful consideration is required when deciding the course of treatment for esophageal hiatal hernias in older adults.

Japan is one of the most rapidly aging countries in the world; accordingly, the number of surgical procedures performed in older adults is also increasing [8]. However, surgical treatments for older patients remain controversial. In general, surgical outcomes are expressed as a balance between the beneficial effects on the patient and the risk of death or sequelae. Therefore, surgical interventions are limited to cases with lower chances of mortality and fewer possible complications. Nevertheless, surgical treatment decisions for older cancer patients, especially those with comorbidities, appear to be primarily based on the surgeon's subjective judgment [9]. Additionally, as a result of discrimination against older adults (ageism), these patients are sometimes not given the option of surgical procedures that are considered to be the standard for younger patients $[8,10]$. Previous studies showed strong correlation between ageism, and physical and psychological risks in older adults [11-13]. Prognosis for older adults is the result of a combination of multiple factors; thus, prognosis may be improved by determining these factors and intervening as appropriate. According to the Guidelines for the Management of Hiatal Hernia [14], surgical interventions are strongly recommended for patients with type II-IV hernias, acute obstruction, and an axial twist. Clinically, cases of obstruction and axial torsion are often handled by surgical interventions because of their urgency. However, hernia types II-IV in older patients may not be operated on, even though it is strongly recommended. Ageism may play a role in this decision.

Furthermore, there is limited research on surgery for older patients with hiatal hernias. Therefore, this study focused on Japan's superaging society to examine surgical interventions for symptomatic esophageal hiatal hernias in older patients and explore treatment outcomes. Our study results may help physicians and surgeons in deciding whether standard surgical interventions should be used for older patients who had been conservatively treated solely because of their age.

\section{Materials and Methods}

\subsection{Research Methods}

This systematic review is prepared according to the preferred reporting items for systematic reviews and meta-analyses (PRISMA) guidelines. The study flow diagram is reported in Figure 1. The study was registered on the international prospective register of systematic reviews (PROSPERO)platform. Registration number: 283059.

\subsection{Search Strategy}

We searched two online databases, Google Scholar and Ichushi, using the following keywords: "shokudourekkouherunia" (esophageal hiatal hernia) and "koureisya" (older adult). Japanese keywords were used, as when relevant keywords in English were used to search Google Scholar and PubMed, no results matching our inclusion criteria were found.

\subsection{Inclusion and Exclusion Criteria}

In our study, older adults were defined as individuals aged 65 or older. Articles published after 1991 on surgeries to treat esophageal hiatal hernias in older patients were included in this study. Conversely, articles published before 1991 and studies or cases involving emergency operations, gastric volvulus, malignancies, intestinal perforations, and shock vitals were excluded. These cases were excluded because malignancy is a prognostic factor in hiatal hernia surgery. Furthermore, cases in which the patients were in poor condition (i.e., shock vitality) were also excluded, as the surgical intervention was performed for life-saving purposes. Patients with gastric volvulus and gastrointestinal obstruction were excluded because surgery was recommended for these conditions on the basis of guidelines for esophageal hiatal hernias. Our inclusion and exclusion criteria are summarized in Table 1. 


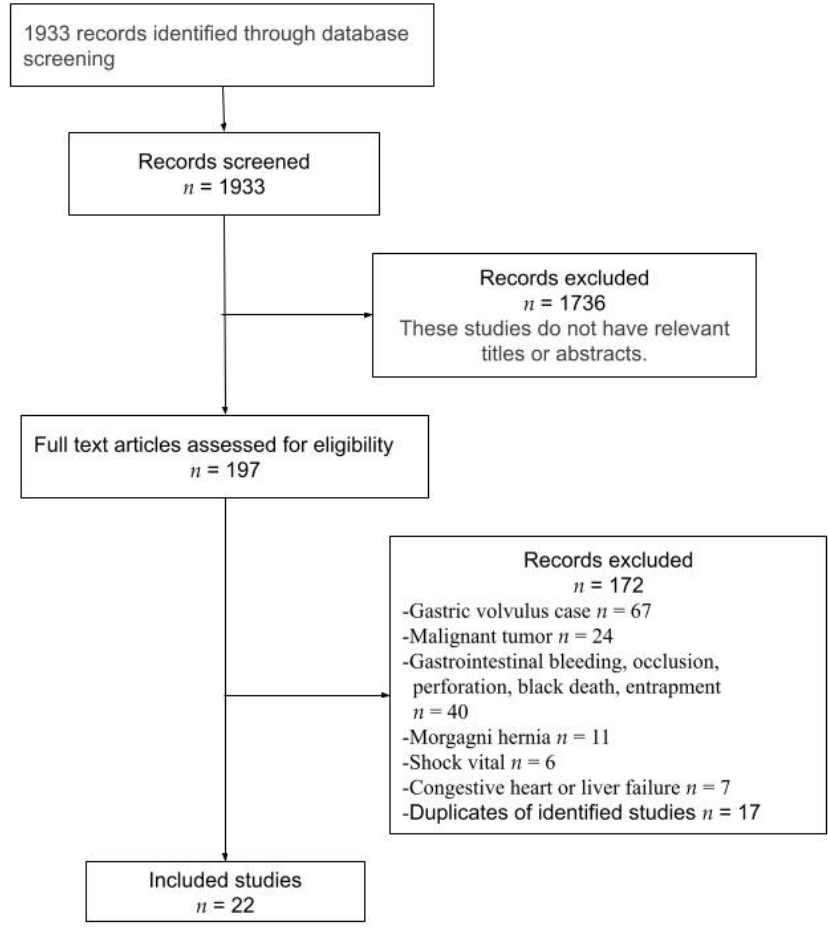

Figure 1. PRISMA flow diagram of the systematic searching process.

Table 1. Inclusion and exclusion criteria.

\begin{tabular}{lll}
\hline \multicolumn{1}{c}{ Inclusion Criteria } & \multicolumn{1}{c}{ Exclusion Criteria } \\
\hline & - Gastric volvulus \\
- Articles published after 1991 on surgeries & - & Malignant tumors \\
to treat esophageal hiatal hernias & Gastrointestinal bleeding, occlusion, \\
Patients aged 65 or older & - Morforation, black death, and entrapment \\
& - Congestive heart failure and liver failure \\
& - Shock vitals \\
& - Duplicates of identified studies \\
\hline
\end{tabular}

\subsection{Data Extraction}

Data extraction was performed by searching for keywords "shokudourekkouherunia" and "koureisya" on Google Scholar and Ichushi.

\subsection{Analysis}

Quantitative and qualitative data are presented as descriptive statistics. Collected data were then divided into topics. We used Microsoft Excel to analyze the gathered data.

\section{Results}

\subsection{Search Results}

No reviews or case summaries on esophageal hiatal hernia in older Japanese patients could be found. Therefore, we focused on and reviewed case reports. A total of 1933 studies that met the abovementioned inclusion criteria were obtained. Of these, 1736 were excluded, as their titles or abstracts were unrelated to the current study. Further, after reviewing the entire texts, 172 were excluded for the following reasons: 67 concerned gastric volvulus; 24, malignant tumors; 40, gastrointestinal bleeding, occlusion, perforation, black death, and entrapment; 11 Morgagni hernias; 7, congestive heart and liver failure; and 6, shock vitals. Lastly, 17 studies were deemed to be duplicates and excluded (Figure 1). In the end, a total of 22 references were identified, and 25 case reports were included in the final analysis (Table 2) [6,15-35]. 
Table 2. Included articles.

\begin{tabular}{|c|c|c|c|c|c|c|c|c|c|c|}
\hline $\begin{array}{l}\text { Last Name of } \\
\text { First Author } \\
\text { (Year of } \\
\text { Publication) }\end{array}$ & $\begin{array}{l}\text { Patient's } \\
\text { Age }\end{array}$ & $\begin{array}{l}\text { Patient's } \\
\text { Sex }\end{array}$ & $\begin{array}{l}\text { Hernia } \\
\text { Type }\end{array}$ & $\begin{array}{l}\text { Reason for } \\
\text { Surgery }\end{array}$ & Past History & $\begin{array}{l}\text { Surgical Procedure } \\
\text { Fundoplication }\end{array}$ & $\begin{array}{l}\text { Postoperative } \\
\text { Discharge }\end{array}$ & Mortality & Complications & $\begin{array}{l}\text { Age-Adjusted } \\
\text { Charlson } \\
\text { ComorbidityIndex }\end{array}$ \\
\hline $\begin{array}{c}\text { Miyake et al. } \\
\text { (1997) [6] }\end{array}$ & 77 & Female & I & Dyspnea & None & $\begin{array}{l}\text { Laparotomy } \\
\text { Nissen, Hill }\end{array}$ & Not stated & None & None & 3 \\
\hline $\begin{array}{l}\text { Yatabe et al. } \\
(2017) \text { [15] }\end{array}$ & 71 & Female & IV & $\begin{array}{l}\text { Dyspnea on } \\
\text { exertion, } \\
\text { heartburn }\end{array}$ & $\begin{array}{c}\text { No } \\
\text { remarkable } \\
\text { findings }\end{array}$ & $\begin{array}{l}\text { Laparoscopy } \\
\text { Toupet }\end{array}$ & 7 days & None & Ileus & 3 \\
\hline $\begin{array}{l}\text { Shikata et al. } \\
\text { (2008) [16] }\end{array}$ & 86 & Female & IV & $\begin{array}{l}\text { Palpitations, } \\
\text { fever, cough }\end{array}$ & $\begin{array}{l}\text { Chronic } \\
\text { subdural } \\
\text { hematoma, } \\
\text { thigh bone } \\
\text { fracture, } \\
\text { dementia }\end{array}$ & $\begin{array}{l}\text { Laparoscopy } \\
\text { Nissen }\end{array}$ & 10 days & None & None & 5 \\
\hline $\begin{array}{l}\text { Kawai et al. } \\
(2019) \text { [17] }\end{array}$ & 94 & Female & III & $\begin{array}{c}\text { Exacerbation } \\
\text { of heart } \\
\text { failure, } \\
\text { dyspnea }\end{array}$ & $\begin{array}{l}\text { Heart failure, } \\
\text { pulmonary } \\
\text { embolism, } \\
\text { bronchial } \\
\text { asthma }\end{array}$ & $\begin{array}{l}\text { Laparoscopy } \\
\text { Hernia repair }\end{array}$ & 16 days & None & None & 5 \\
\hline $\begin{array}{l}\text { Saito et al. } \\
\text { (2017) [18] }\end{array}$ & 82 & Female & IV & $\begin{array}{c}\text { Repetitive } \\
\text { postprandial } \\
\text { syncope, } \\
\text { cardiac } \\
\text { compression } \\
\text { due to hiatal } \\
\text { hernia }\end{array}$ & $\begin{array}{l}\text { Diabetes, } \\
\text { anemia }\end{array}$ & $\begin{array}{l}\text { Laparoscopy } \\
\text { Hernia repair }\end{array}$ & Not stated & None & None & 5 \\
\hline $\begin{array}{l}\text { Yagi et al. } \\
\text { (2018) [19] }\end{array}$ & 81 & Male & IV & $\begin{array}{c}\text { Hepatic } \\
\text { dysfunction }\end{array}$ & $\begin{array}{l}\text { Hypertension, } \\
\text { aortic stenosis }\end{array}$ & $\begin{array}{l}\text { Laparoscopy } \\
\text { Nissen }\end{array}$ & 12 days & None & None & 5 \\
\hline $\begin{array}{l}\text { Okumura et al. } \\
\text { (2015) [20] }\end{array}$ & 71 & Female & IV & $\begin{array}{l}\text { Dyspnea, } \\
\text { vomiting }\end{array}$ & $\begin{array}{l}\text { Hypertension, } \\
\text { uterine } \\
\text { fibroids }\end{array}$ & $\begin{array}{l}\text { Laparoscopy } \\
\text { Nissen }\end{array}$ & 16 days & None & None & 4 \\
\hline
\end{tabular}


Table 2. Cont.

\begin{tabular}{|c|c|c|c|c|c|c|c|c|c|c|}
\hline $\begin{array}{l}\text { Last Name of } \\
\text { First Author } \\
\text { (Year of } \\
\text { Publication) }\end{array}$ & $\begin{array}{l}\text { Patient's } \\
\text { Age }\end{array}$ & $\begin{array}{l}\text { Patient's } \\
\text { Sex }\end{array}$ & $\begin{array}{l}\text { Hernia } \\
\text { Type }\end{array}$ & $\begin{array}{l}\text { Reason for } \\
\text { Surgery }\end{array}$ & Past History & $\begin{array}{l}\text { Surgical Procedure } \\
\text { Fundoplication }\end{array}$ & $\begin{array}{l}\text { Postoperative } \\
\text { Discharge }\end{array}$ & Mortality & Complications & $\begin{array}{l}\text { Age-Adjusted } \\
\text { Charlson } \\
\text { ComorbidityIndex }\end{array}$ \\
\hline $\begin{array}{l}\text { Mimatsu et al. } \\
\text { (2014) [21] }\end{array}$ & 82 & Female & II & Dysphagia & $\begin{array}{l}\text { Hypertension, } \\
\text { sinusoidal } \\
\text { failure } \\
\text { syndrome, } \\
\text { cerebral } \\
\text { infarction, } \\
\text { dementia }\end{array}$ & $\begin{array}{c}\text { Laparoscopy } \\
\text { Nissen }\end{array}$ & Not stated & None & None & 7 \\
\hline $\begin{array}{l}\text { Masayuki et al. } \\
\text { (2015) [22] }\end{array}$ & 69 & Male & III & $\begin{array}{l}\text { Heartburn, } \\
\text { dyspnea }\end{array}$ & $\begin{array}{l}\text { Hypertension, } \\
\text { kidney failure }\end{array}$ & $\begin{array}{c}\text { Laparoscopy } \\
\text { Toupet }\end{array}$ & 11 days & None & None & 5 \\
\hline $\begin{array}{l}\text { Masayuki et al. } \\
\text { (2015) [22] }\end{array}$ & 81 & Female & III & Vomiting & Asthma & $\begin{array}{c}\text { Laparoscopy } \\
\text { Toupet }\end{array}$ & 21 days & None & None & 4 \\
\hline $\begin{array}{l}\text { Nonaka et al. } \\
\text { (2013) [23] }\end{array}$ & 86 & Female & IV & $\begin{array}{l}\text { Dyspnea, } \\
\text { wheezing }\end{array}$ & Not stated & $\begin{array}{c}\text { Laparotomy } \\
\text { Nissen }\end{array}$ & About 90 days & None & $\begin{array}{l}\text { Upper gas- } \\
\text { trointestinal } \\
\text { obstruction }\end{array}$ & - \\
\hline $\begin{array}{l}\text { Okada et al. } \\
\text { (2009) [25] }\end{array}$ & 74 & Female & III & $\begin{array}{l}\text { Chest pain, } \\
\text { vomiting }\end{array}$ & $\begin{array}{c}\text { Asthma, } \\
\text { GERD, hyper- } \\
\text { lipidemia, } \\
\text { postoperative } \\
\text { lung cancer, } \\
\text { hypertension }\end{array}$ & $\begin{array}{l}\text { Laparotomy } \\
\text { Hernia repair }\end{array}$ & 73 days & None & $\begin{array}{l}\text { Pyothorax } \\
\text { Pneumonia }\end{array}$ & 4 \\
\hline $\begin{array}{l}\text { Hirashita et al. } \\
\text { (2008) [26] }\end{array}$ & 93 & Female & III & $\begin{array}{c}\text { Vomiting, } \\
\text { aspiration } \\
\text { pneumonia }\end{array}$ & Hypertension & $\begin{array}{c}\text { Laparoscopy } \\
\text { Nissen }\end{array}$ & 7 days & None & None & 5 \\
\hline
\end{tabular}


Table 2. Cont.

\begin{tabular}{|c|c|c|c|c|c|c|c|c|c|c|}
\hline $\begin{array}{l}\text { Last Name of } \\
\text { First Author } \\
\text { (Year of } \\
\text { Publication) }\end{array}$ & $\begin{array}{l}\text { Patient's } \\
\text { Age }\end{array}$ & $\begin{array}{l}\text { Patient's } \\
\text { Sex }\end{array}$ & $\begin{array}{c}\text { Hernia } \\
\text { Type }\end{array}$ & $\begin{array}{l}\text { Reason for } \\
\text { Surgery }\end{array}$ & Past History & $\begin{array}{l}\text { Surgical Procedure } \\
\text { Fundoplication }\end{array}$ & $\begin{array}{l}\text { Postoperative } \\
\text { Discharge }\end{array}$ & Mortality & Complications & $\begin{array}{c}\text { Age-Adjusted } \\
\text { Charlson } \\
\text { ComorbidityIndex }\end{array}$ \\
\hline $\begin{array}{l}\text { Hirashita et al. } \\
\text { (2008) [26] }\end{array}$ & 93 & Female & III & Vomiting & None & $\begin{array}{l}\text { Laparoscopy } \\
\text { Nissen }\end{array}$ & 7 days & None & None & 4 \\
\hline $\begin{array}{l}\text { Eda et al. } \\
(2000) \text { [27] }\end{array}$ & 79 & Female & IV & Vomiting & $\begin{array}{c}\text { Uterine } \\
\text { myoma, } \\
\text { diabetes } \\
\text { mellitus, } \\
\text { hypertension, } \\
\text { chronic } \\
\text { bronchitis }\end{array}$ & $\begin{array}{l}\text { Laparotomy } \\
\text { Hernia repair }\end{array}$ & 24 days & None & Pneumonia & 5 \\
\hline $\begin{array}{c}\text { Matsui et al. } \\
\text { (1992) [28] }\end{array}$ & 87 & Female & IV & $\begin{array}{l}\text { Chest pain, } \\
\text { multiple } \\
\text { gastric ulcers }\end{array}$ & $\begin{array}{l}\text { Lumbar spine } \\
\text { compression } \\
\text { fracture }\end{array}$ & $\begin{array}{l}\text { Laparotomy } \\
\text { Hill }\end{array}$ & Not stated & None & $\begin{array}{l}\text { Pulmonary } \\
\text { complications }\end{array}$ & 4 \\
\hline $\begin{array}{l}\text { Hirai et al. } \\
\text { (2011) [29] }\end{array}$ & 84 & Female & IV & $\begin{array}{c}\text { Aspiration } \\
\text { pneumonia, } \\
\text { vomiting, } \\
\text { fever }\end{array}$ & $\begin{array}{c}\text { Reflux } \\
\text { esophagitis, } \\
\text { chronic } \\
\text { bronchiectasis }\end{array}$ & $\begin{array}{l}\text { Laparoscopy } \\
\text { Nissen }\end{array}$ & 10 days & None & None & 5 \\
\hline $\begin{array}{l}\text { Uno et al. } \\
\text { (2015) [30] }\end{array}$ & 83 & Female & IV & Vomiting & $\begin{array}{c}\text { Hypertension, } \\
\text { dementia }\end{array}$ & $\begin{array}{l}\text { Laparoscopy } \\
\text { Toupet }\end{array}$ & 14 days & None & None & 6 \\
\hline $\begin{array}{l}\text { Kim et al. } \\
\text { (2011) [31] }\end{array}$ & 88 & Female & III & $\begin{array}{c}\text { Aspiration } \\
\text { pneumonia, } \\
\text { multiple } \\
\text { gastric ulcers, } \\
\text { vomiting, loss } \\
\text { of appetite }\end{array}$ & $\begin{array}{l}\text { Cerebral } \\
\text { infarction, } \\
\text { cataract }\end{array}$ & $\begin{array}{l}\text { Laparotomy } \\
\text { Hernia repair }\end{array}$ & Not stated & None & Not stated & 5 \\
\hline $\begin{array}{l}\text { Kajitani et al. } \\
\text { (2016) [32] }\end{array}$ & 67 & Female & IV & $\begin{array}{l}\text { Abdominal } \\
\text { pain, } \\
\text { constipation }\end{array}$ & $\begin{array}{l}\text { Cesarean } \\
\text { section, } \\
\text { rheumatoid } \\
\text { arthritis, acute } \\
\text { myocardial } \\
\text { infarction, } \\
\text { humerus } \\
\text { fracture }\end{array}$ & $\begin{array}{l}\text { Laparotomy } \\
\text { Toupet }\end{array}$ & $\begin{array}{l}108 \text { days after } \\
\text { reoperation }\end{array}$ & None & $\begin{array}{l}\text { Septal vertical } \\
\text { ulcer, } \\
\text { subtransverse } \\
\text { septal abscess, } \\
\text { resurgery }\end{array}$ & 3 \\
\hline
\end{tabular}


Table 2. Cont.

\begin{tabular}{|c|c|c|c|c|c|c|c|c|c|c|}
\hline $\begin{array}{l}\text { Last Name of } \\
\text { First Author } \\
\text { (Year of } \\
\text { Publication) }\end{array}$ & $\begin{array}{l}\text { Patient's } \\
\text { Age }\end{array}$ & $\begin{array}{l}\text { Patient's } \\
\text { Sex }\end{array}$ & $\begin{array}{l}\text { Hernia } \\
\text { Type }\end{array}$ & $\begin{array}{l}\text { Reason for } \\
\text { Surgery }\end{array}$ & Past History & $\begin{array}{l}\text { Surgical Procedure } \\
\text { Fundoplication }\end{array}$ & $\begin{array}{c}\text { Postoperative } \\
\text { Discharge }\end{array}$ & Mortality & Complications & $\begin{array}{l}\text { Age-Adjusted } \\
\text { Charlson } \\
\text { ComorbidityIndex }\end{array}$ \\
\hline \multirow{2}{*}{ Iyobe (1994) [33] } & 72 & Female & $\begin{array}{c}\text { Not } \\
\text { stated }\end{array}$ & $\begin{array}{c}\text { GERD, } \\
\text { vomiting }\end{array}$ & Not stated & $\begin{array}{l}\text { Laparotomy } \\
\text { Nissen }\end{array}$ & Not stated & None & None & - \\
\hline & 76 & Female & $\begin{array}{l}\text { Not } \\
\text { stated }\end{array}$ & $\begin{array}{c}\text { GERD, } \\
\text { vomiting }\end{array}$ & Not stated & $\begin{array}{l}\text { Laparotomy } \\
\text { Nissen }\end{array}$ & Not stated & None & None & - \\
\hline $\begin{array}{l}\text { Mori et al. } \\
\text { (2011) [34] }\end{array}$ & 100 & Female & IV & $\begin{array}{c}\text { Aspiration } \\
\text { pneumonia, } \\
\text { ARDS, } \\
\text { vomiting } \\
\text { blood }\end{array}$ & $\begin{array}{c}\text { Gallstone, } \\
\text { deformed } \\
\text { spine, heart } \\
\text { failure }\end{array}$ & $\begin{array}{c}\text { Laparoscopy } \\
\text { Toupet }\end{array}$ & 13 days & None & None & 5 \\
\hline $\begin{array}{l}\text { Ishizakii et al. } \\
\text { (1999) [35] }\end{array}$ & 80 & Female & I & $\begin{array}{c}\text { Dyspnea on } \\
\text { exertion }\end{array}$ & Asthma & $\begin{array}{l}\text { Laparotomy } \\
\text { Hernia repair }\end{array}$ & Not stated & None & None & 4 \\
\hline
\end{tabular}

GERD: gastroesophageal reflux disease; ARDS: acute respiratory distress syndrome. 


\subsection{Demographics}

The mean age of the patients was 81.4 years with a variance of 67.36. The maleto-female ratio was $1: 11.5$. The most common reason for surgery was vomiting (48\%), followed by dyspnea (28\%) and chest pain ( $8 \%$ ). Other symptoms were heartburn, fever, worsening heart failure, postprandial syncope, abnormal liver function, wheezing, weight loss, anorexia, abdominal pain, and constipation.

\subsection{Medical History}

Hypertension (36\%) was the most common medical condition. Other conditions included asthma, dementia, heart failure, diabetes, stroke, reflux esophagitis, pulmonary embolism, aortic valve stenosis, hiatal hernia, lumbar compression fracture, rheumatoid arthritis, acute myocardial infarction, humeral fracture, cholelithiasis, and osteoarthritis.

\subsection{Types of Esophageal Hiatal Hernias}

Type IV hernias were the most common, accounting for $48 \%$ of the cases, followed by type III at $32 \%$; type I, undescribed at $8 \%$; and type II at $4 \%$.

\subsection{Surgical Form}

There were $15(60 \%)$ laparoscopic and 10 (40\%) laparotomy cases. For fundoplication, 12 patients underwent Nissen repair, 6 Toupet repair, 2 Hill repair, and 6 only hernia repair.

\subsection{Age-Adjusted Charlson Comorbidity Index}

Past history was noted in 22 cases, and the age-adjusted Charlson Comorbidity Index (CCI) [36] could be calculated: 3 cases had CCI3, 7 cases had CCI4, 10 cases had CCI5, 1 case had CCI6, and 1 case had CCI7. The mean CCI was 4.54 .

\subsection{Outcome}

For the 25 cases, mean postoperative course was 26.47 days (range of 7-108 days) until hospital discharge, and no cases of perioperative death were reported. Furthermore, no cases of postoperative recurrence were found. Postoperative complications were reported in 1 of 15 laparoscopic cases $(6.7 \%)$ and 5 of 10 laparotomy cases (50\%). The mean postoperative hospital discharge time was 11.9 days (range of 7-21) in 13 of 15 laparoscopic cases, while it was 73.8 days (range of 24-108 days) in 4 of 10 laparotomic cases. Regarding the year of publication, six cases of laparotomy were published between 1991 and 2000, one between 2001 and 2010, and three between 2011 and 2021. For laparoscopic cases, 3 were reported between 2001 and 2010, and 12 from 2011 to 2021; however, no cases were reported from 1991 to 2000. Almost no reports described postoperative quality of life, and as such, this aspect was not included in the data collection for this study.

\subsection{Study Characteristics}

This systematic review aimed to analyze surgical interventions for symptomatic esophageal hiatal hernias in older Japanese patients and to explore treatment outcomes. We identified 22 references, and 25 case reports were included in the final analysis.

\section{Discussion}

In this systematic review, we aimed to analyze surgical interventions for older Japanese patients with symptomatic esophageal hiatal hernia and to explore treatment outcomes. We identified 22 references, and 25 case reports were included in the final analysis.

Previous studies [37] reported 5.4-17\% mortality rates for emergency surgery, and an average mortality rate of $1.38 \%(0-5.2 \%)$ for laparoscopic standby surgery. Although the mean age of patients in this study was particularly high at 81.4 years, the average time to postoperative discharge was 26.47 days, and no cases of perioperative death were reported. We found a standby surgery mortality rate of $0 \%$, which is better than that reported in a previous study (1.38\%) [37]. Postoperative prognosis was good for patients 
who had undergone surgery, even those who were at a more advanced age. Previous studies showed strong correlation between ageism, and physical and psychological risks in older adults [11-13,38]. This supports the possibility that multiple factors contribute to the prognosis of older adults, and that age is not the only relevant biological factor. The mean $\mathrm{CCI}$ of the 22 patients who could be considered for $\mathrm{CCI}$ in this study was 4.54; the relative risk of death after 10 years was 4.40 for CCI4, and 6.38 for CCI5 rather than CCI0. However, one drawback of CCI is that activities of daily living (ADL) are is not taken into account. ADL is a prognostic factor among the elderly, and an association between walking speed and survival was reported [39]. In this study, most of the case reports did not describe ADL, and the lack of information on ADL is a limitation of this study. It is crucial to determine the indication for surgery by considering ADL and the patient's intention, even if the patient is at high risk because of predictors such as CCI. Consideration of prognostic factors and appropriate interventions may improve the prognosis of older patients with esophageal hiatal hernias. Clinicians also need to be aware of the unconscious bias of ageism.

In this study, $92 \%$ of the patients were women. Their reasons for undergoing surgery were dyspnea, vomiting, orbital pain, difficulty in food intake, and other complications such as repeated aspiration pneumonia and the exacerbation of reflux esophagitis. Types III and IV accounted for most of the hernia cases. Statistically, esophageal hiatal hernia is more common in men across all age groups [1]; however, in this study, most patients were women. The reason for this discrepancy may be that types III and IV esophageal hiatal hernias increase with age in women owing to postmenopausal osteoporosis-associated gibbus deformity and habitual or deformed posterior lumbar curvature [1].

Among the excluded records $(n=172)$, nine were emergency surgery cases, and six of these surgeries were on male patients. Emergency surgery cases are usually more common in men. Older men are less attentive to their health than their female counterparts are [40]; this finding may explain the high number of men who underwent emergency surgery after their symptoms had worsened. Furthermore, married men are more concerned about their health than those who are separated or widowed are. This may indicate the influence of marriage on men's health. Men tend to be less cognizant of caring for people of the same gender, regardless of their relationship, and are more likely to care for people of the opposite gender (e.g., spouses or partners). This suggests that partners and spouses may influence the behavior of men who do not seek medical attention until their condition worsens. Connections with other people decrease with age [41], but men, in particular, are expected to continue their connections with individuals of the opposite gender.

Regarding surgical interventions, laparoscopic surgery was performed in 15 cases, while laparotomy was performed in 10. Postoperative complications were reported in 1 of 15 laparoscopic cases $(6.7 \%)$ and 5 of 10 laparotomy cases $(50 \%)$. The mean postoperative hospital discharge time was 11.9 days (range of 7-21 days) in 13 of 15 laparoscopic cases. In contrast, the mean postoperative hospital discharge time was 73.8 days (range of 24-108 days) in 4 of 10 laparotomic cases. Laparoscopic surgery was associated with shorter postoperative hospital stays than laparotomy surgery was. The Nissen and Toupet methods for open surgery were used in clinical practice; however, after the report of Dallemagne et al. [42] on laparoscopic surgery in 1991, this surgical method also became widespread in Japan. Important aspects of surgery include the return of prolapsed organs, closure of the esophageal hiatus, formation of the cardia to prevent regurgitation, and the fixation of twist prevention; however, numerous sutures are required, and the high recurrence rate was initially a problem [43]. Over the years, the feasibility and safety of laparoscopic surgery were reported $[44,45]$. There was no difference in long-term prognosis between laparoscopic surgery and open surgery [46,47]. Nonetheless, laparoscopic surgery appears to ensure quicker hospital discharge [48]. The study results also support this fact. Laparoscopic surgery is expected to be effective for older adults for several reasons, including minimal invasiveness, better cosmetic appearance for the patient, and the ability to secure the surgeon's visual field. Regarding year of publication, six cases of laparotomy were 
published between 1991 and 2000, one between 2001 and 2010, and three between 2011 and 2021. Results also reflect an increase in the number of laparoscopic surgeries.

Despite the significance of the findings, this study had some limitations. First, only the Japanese literature was included in the study; thus, racial differences in the findings must be considered. Second, most of the inquiry targets were case reports; therefore, cases with surgical failures may not have been included.

\section{Conclusions}

Overall, results suggested that prognosis was good in the included cases, although the average age of the patients was 81.4 years. The surgical method appeared to positively influence patient outcomes. The average discharge time was 26.47 days, and no cases of perioperative death were found.

On the basis of the results, even if there is no obvious surgical indicator for esophageal hiatal hernia in older adults (e.g., axial torsion or acute obstructive symptoms), aggressive surgical interventions might still improve the quality of life of symptomatic patients. Therefore, clinicians need to be aware of their unconscious bias of ageism while treating older patients, and reach decisions related to surgical indications on the basis of the patient's prognostic factors. Further collaboration between surgeons and general practitioners specializing in reaching such decisions helps in improving the quality of life of older adults in a rapidly aging society such as Japan. In conclusion, the best method for treating esophageal hiatal hernia in older adults should be determined with a consideration of multiple factors and not just age alone.

Author Contributions: Conceptualization, Y.H., K.S. and R.O.; methodology, K.S.; software, K.S.; validation, K.S.; formal analysis, Y.H., K.S. and R.O.; investigation, Y.H., K.S. and R.O.; resources, Y.H., K.S., and R.O.; data curation, Y.H., K.S.; writing-original draft preparation, Y.H., K.S., and R.O.; writing-review and editing, Y.H., K.S., and R.O.; visualization, Y.H.; supervision, C.S.; project administration, R.O. All authors have read and agreed to the published version of the manuscript.

Funding: This research received no external funding.

Institutional Review Board Statement: Not applicable.

Informed Consent Statement: Not applicable.

Data Availability Statement: All relevant datasets in this study are presented in the manuscript.

Acknowledgments: We are very grateful to Ohta for teaching us about the significance of submitting a paper, the process of writing a paper, and the challenges therein. We are also grateful to Sano for his discussions and for extending financial support.

Conflicts of Interest: The authors declare no conflict of interest.

\section{References}

1. Kusano, M.; Kouzu, T.; Kawano, T.; Ohara, S. The prevalence of hiatus hernia in the Japanese. Gastroenterol. Endosc. 2005, 47, 962-973. [CrossRef]

2. Aoki, T.; Kashiwagi, H.; Omura, N. Hiatal hernia. J. Clin. Gastroenterol. 2000, 15, 757-764.

3. Kashiwagi, H.; Omura, N.; Ishibashi, Y. Esophageal hiatal hernia. J. Clin. Gastroenterol. 2008, 23, 833-840.

4. Hiroshi, I.G.A. X-ray finding of esophageal hiatsu hernia-Classification of degree of hernia. Jpn. J. Gastroenterol. Surg. 1985, 18, 1-7.

5. Makuuchi, H. Clinical study of esophageal hiatal hernia-Diagnostic criteria and degree classification of hiatal hernia. J. Jpn. Soc. Gastroenterol. 1982, 79, 1557-1567.

6. Miyake, Y.; Fujimoto, T.; Ikenaga, M.; Doi, S.; Hakata, N.; Naoi, M. A case of large sliding hiatal hernia of the esophagus associated with dyspnea. J. Jpn. Surg. Assoc. 1997, 58, 1014-1017. [CrossRef]

7. Kinugasa, K.; Yasuoka, S.; Matsuda, T.; Nishiyama, N. A case of esophageal hiatus hernia with paroxysmal supraventricular tachycardia. J. Jpn. Surg. Assoc. 1998, 59, 1825-1828. [CrossRef]

8. Ulander, K.; Jeppsson, B.; Grahn, G. Quality of life and independence in activities of daily living preoperatively and at follow-up in patients with colorectal cancer. Support. Care Cancer 1997, 5, 402-409. [CrossRef] 
9. Amemiya, T.; Oda, K.; Ando, M.; Kawamura, T.; Kitagawa, Y.; Okawa, Y.; Yasui, A.; Ike, H.; Shimada, H.; Kuroiwa, K.; et al. Activities of daily living and quality of life of elderly patients after elective surgery for gastric and colorectal cancers. Ann. Surg. 2007, 246, 222-228. [CrossRef]

10. Ware, J.E.; Kosinski, M.; Tuner-Bowker, D.M.; Gandek, B. How to Score Version 2 of the SF-12 Health Survey (with a Supplement Documenting Version 1); Health Assessment Lab: Boston, MA, USA, 2002.

11. Sloane, P.D.; Gruber-Baldini, A.L.; Zimmerman, S.; Roth, M.; Watson, L.; Boustani, M.; Magaziner, J.; Hebel, J.R. Medication undertreatment in assisted living settings. Arch. Intern. Med. 2004, 164, 2031-2037. [CrossRef]

12. Lang, P.O.; Hasso, Y.; Dramé, M.; Vogt-Ferrier, N.; Prudent, M.; Gold, G.; Michel, J.P. Potentially inappropriate prescribing including under-use amongst older patients with cognitive or psychiatric co-morbidities. Age Ageing 2010, 39, 373-381. [CrossRef] [PubMed]

13. Chang, E.S.; Kannoth, S.; Levy, S.; Wang, S.-Y.; Lee, J.E.; Levy, B.R. Global reach of ageism on older persons' health: A systematic review. PLoS ONE 2020, 15, e0220857:1-e0220857:24. [CrossRef] [PubMed]

14. Kohn, G.P.; Price, R.R.; Demeester, S.R.; Zehetner, J.; Muensterer, O.J.; Awad, Z.T.; Mittal, S.K.; Richardson, W.S.; Stefanidis, D.; Fanelli, R.D.; et al. Guidelines for the Management of Hiatal Hernia; Society of American Gastrointestinal and Endoscopic Surgeons: Los Angeles, CA, USA, 2013.

15. Yatabe, K.; Ozawa, S.; Ito, E.; Oguma, J.; Kazuno, A.; Nitta, M.; Ninomiya, Y. Late esophageal wall injury after mesh repair for large esophageal hiatal hernia: A case report. Surg. Case Rep. 2017, 3, 125:1-125:7. [CrossRef] [PubMed]

16. Shikata, H.; Kohno, M.; Kanno, M.; Matsubara, J. A case of endoscopic surgery in an octogenarian for large esophageal hernia oppressing the lung and heart. J. Jpn. Assoc. Chest Surg. 2008, 22, 649-653. [CrossRef]

17. Kawai, T.; Takehana, T.; Endou, H.; Yamamoto, K. Laparoscopic repair and percutaneous endoscopic helical fistula: A case of upside down esophageal hiatal hernia in a very elderly patient. Operation 2019, 73, 1133-1137.

18. Saito, H.; Miyazaki, T.; Sohda, M.; Sakai, M.; Honjyo, H.; Kumakura, Y.; Yoshida, T.; Yokobori, T.; Kurosawa, K.; Kuwano, H. Postprandial cardiogenic syncope caused by gastric polyp-induced pyloric obstruction in an elderly woman with a giant hiatal hernia: A case report. Surg. Case Rep. 2017, 3, 124:1-124:4. [CrossRef]

19. Yagi, D.; Takinami, Y.; Sugano, M.; Hattori, Y. Laparoscopic repair of esophageal hiatal hernia with cholestasis secondary to pancreatic prolapse. J. Jpn. Coll. Surg. 2018, 43, 30-35. [CrossRef]

20. Okumura, K.; Iwami, M.; Baba, Y.; Honma, K.; Tanaka, M.; Ikezoe, K. Laparoscopic repair using a new ventral leper hernia mesh: A case of giant esophageal hiatal hernia. J. Clin. Exp. Med. 2015, 92, 1599-1602.

21. Mimatsu, K.; Oida, T.; Kida, K.; Fukino, N.; Kawasaki, A.; Kano, H.; Kuboi, Y.; Amano, S. Simultaneous laparoscopic Nissen fundoplication and percutaneous endoscopic gastrostomy to treat an elderly patient with a large paraesophageal hernia: A case report. Asian J. Endosc. Surg. 2014, 7, 165-168. [CrossRef]

22. Nakau, M.; Yanai, S.; Tachibana, T.; Kanou, M.; Mitsuyoshi, A.; Yanagibashi, K. Laparoscopic repair with mesh for giant type III hiatal hernia. J. Otsu Munic. Hosp. 2015, 16, 12-16.

23. Nonaka, K.; Sugiyama, T.; Amaoka, N.; Kato, H.; Shiroko, T.; Yoshida, K. Esophageal hiatal hernia of the "Upside Down Stomach" in an elderly-Report of a case. J. Jpn. Surg. Assoc. 2013, 74, 3016-3021. [CrossRef]

24. Ishino, Y.; Ohi, M.; Hiro, J.; Oue, M.; Mohri, Y.; Kusunoki, M. Esophageal hiatal herma complicated with parahiatal hernia diagnosed and treated by effective laparoscopic surgery. Jpn. Soc. Endosc. Surg. 2012, 17, 367-372.

25. Okada, M.; Tao, H.; Yamane, M.; Oto, T.; Sano, Y.; Toyooka, S. A case of hiatus hernia which progressed after lung surgery and required hernia repair due to severe cardio-pulmonary failure. J. Jpn. Assoc. Chest Surg. 2009, 23, 881-885. [CrossRef]

26. Hirashita, T.; Etoh, T.; Yasuda, K.; Noguchi, T.; Shiraishi, N.; Kitano, S. A report of two extremely elderly cases of esophageal hiatal hernia successfully treated by laparoscopic surgery. Jpn. Soc. Endosc. Surg. 2008, 13, 763-767.

27. Eda, I.; Suemitsu, K.; Yano, M.; Sutoh, I.; Otsuka, A. A case of esophageal hiatal hernia with incarcerated stomach, duodenum and transverse colon. J. Jpn. Surg. Assoc. 2000, 61, 2631-2635. [CrossRef]

28. Matsui, S.; Nishiyama, H.; Fujita, S.; Tabata, B.; Fujimori, T.; Ishikawa, Y. A case of upside down stomach type esophageal hiatus Hernia. J. Jpn. Soc. Clin. Surg. 1992, 53, 2130-2134. [CrossRef]

29. Hirai, K.; Yoshinari, D.; Komatsu, K.; Sato, T.; Tanaka, K.; Takahashi, N.; Ogawa, H.; Toya, H.; Totsuka, O.; Sunose, Y.; et al. A case of esophageal hiatal hernia-induced repeated aspiration pneumonia in an elderly patient successfully treated with laparoscopic fundoplication. Kitakanto Med. J. 2011, 61, 193-197. [CrossRef]

30. Uno, K.; Omura, N.; Iino, T.; Kubo, T. Surgical repair of esophageal hiatal hernia after spontaneous reduction of upside-down stomach. J. Jpn. Surg. Assoc. 2015, 76, 1673-1678. [CrossRef]

31. Kim, M.; Kuroda, T.; Yoshikumi, H.; Miyasaka, N.; Nakamata, S.; Maekawa, H.; Sakata, H.; Toyoda, H.; Koyama, H.; Nomura, R.; et al. A case of incarcerated hiatal hernia with multiple gastric ulcers needed surgical approach. Prog. Dig. Endosc. 2011, 78, 80-81. [CrossRef]

32. Kajitani, S.; Yamada, Y.; Ootani, Y.; Kurayoshi, K.; Wakatsuki, T.; Kohno, K.; Yoshioka, H. A case of postoperative perforation of esophageal hiatal hernia with mesh. Med. J. Matsue City Hosp. 2016, 20, 33-40.

33. Iyobe, T.; Kawamura, T.; Shima, Y.; Sawasaki, K.; Haryo, S.; Fujita, H. Operative cases of sliding esophageal hiatal hernia-Four cases treated by fundoplication of Nissen procedure with Dor's modification. Jpn. J. Gastroenterol. Surg. 1994, 27, 78-81. [CrossRef] 
34. Mori, M.; Akutsu, Y.; Hayashi, H.; Kawahira, H.; Syuto, K.; Hanari, N.; Ikeda, N.; Sadahiro, T.; Oda, S.; Matsubara, H. A case of 100-year-old woman successfully treated for upside down stomach with laparoscopic surgery. Jpn. J. Gastroenterol. Surg. 2011, 44, 1389-1396. [CrossRef]

35. Ishizaki, M.; Okano, K. A case of esophageal hernia with severe dyspnea on effort. J. Jpn. Surg. Assoc. 1999, 60, 2632-2636. [CrossRef]

36. Charlson, M.; Szatrowski, T.P.; Peterson, J.; Gold, J. Validation of a combined comorbidity index. J. Clin. Epidemiol. 1994, 47, 1245-1251. [CrossRef]

37. Stylopoulos, N.; Gazelle, G.S.; Rattner, D.W. Paraesophageal hernias: Operation or observation? Ann. Surg. 2002, $236,492-501$. [CrossRef]

38. Amano, S.; Ohta, R.; Sano, C. Recognition of anemia in elderly people in a rural community hospital. Int. J. Environ. Res. Public Health 2021, 18, 11179. [CrossRef] [PubMed]

39. Studenski, S.; Perera, S.; Patel, K.; Rosano, C.; Faulkner, K.; Inzitari, M.; Brach, J.; Chandler, J.; Cawthon, P.; Connor, E.B.; et al. Gait speed and survival in older adults. JAMA 2011, 305, 50-58. [CrossRef]

40. Tanaka, Y.; Ishi, K. Basic research on health-related behavior in adulthood. Bull. Fac. Hum. Stud. Seisen Jogakuin College 2021, 18. [CrossRef]

41. Aoki, T.; Yamamoto, Y.; Ikenoue, T.; Urushibara-Miyachi, Y.; Kise, M.; Fujinuma, Y.; Fukuhara, S. Social isolation and patient experience in older adults. Ann. Fam. Med. 2018, 16, 393-398. [CrossRef]

42. Dallemagne, B.; Weerts, J.M.; Jehaes, C.; Markiewicz, S.; Lombard, R. Laparoscopic Nissen fundoplication: Preliminary report. Surg. Laparosc. Endosc. 1991, 1, 138-143.

43. Hashemi, M.; Peters, J.H.; DeMeester, T.R.; Huprich, J.E.; Quek, M.; Hagen, J.A.; Crookes, P.F.; Theisen, J.; DeMeester, S.R.; Sillin, L.F.; et al. Laparoscopic repair of large type III hiatal hernia: Objective follow up reveals high recurrence rate. J. Am. Coll. Surg. 2000, 190, 553-560. [CrossRef]

44. Diaz, S.; Brunt, L.M.; Klingensmith, M.E.; Frisella, P.M.; Soper, N.J. Laparoscopic paraesophageal hernia repair, a challenging operation: Medium-term outcome of 116 patients. J. Gastrointest. Surg. 2003, 7, 59-67. [CrossRef]

45. Swanstrom, L.L.; Jobe, B.A.; Kinzie, L.R.; Horvath, K.D. Esophageal motility and outcomes following laparoscopic paraesophageal hernia repair and fundoplication. Am. J. Surg. 1999, 177, 359-363. [CrossRef]

46. Draaisma, W.A.; Gooszen, H.G.; Tournoij, E.; Broeders, I.A. Controversies in paraesophageal hernia repair: A review of literature. Surg. Endosc. 2005, 19, 1300-1308. [CrossRef] [PubMed]

47. Draaisma, W.A.; Rijnhart-de Jong, H.G.; Broeders, I.A.; Smout, A.J.; Furnee, E.J.; Gooszen, H.G. Five-year subjective and objective results of laparoscopic and conventional Nissen fundoplication: A randomized trial. Ann. Surg. 2006, 244, 34-41. [CrossRef] [PubMed]

48. Murata, R.; Kobayashi, N.; Watanabe, Y.; Echizenya, H. A case of esophageal hernia with an upside-down stomach. J. Jpn. Coll. Surg. 2019, 44, 203-208. [CrossRef] 